\title{
Ramseyer's Battle for Monetary Reform
}

\section{DAVID L. PORTER}

The University of Iowa Libraries contain the papers of several Iowans who served in Congress during the era of the Great Depression. Republicans Edward H. Campbell, Lester J. Dickinson, Benton F. Jensen, Karl M. LeCompte, Fred D. Letts, Christian William Ramseyer, and Thomas J. B. Robinson, along with Democrats Frederick L. Biermann, Edward C. Eicher, and Clyde L. Herring, have collections there. This article describes the role of Representative Christian William Ramseyer of Bloomfield, Iowa, in seeking enactment of monetary-reform legislation in the 1931-32 period. ${ }^{1}$

Ramseyer was an influential member of the Iowa congressional delegation. With the exception of House Agriculture Committee Chairman Gilbert N. Haugen of Norwood, Ramseyer had sorved longer in the House than any other congressman from Iowa. Born on a farm near Collinsville, Ohio, in March 1875, Ramseyer moved with his family at age 12 to Davis County, Iowa, and settled near Pulaski. After attending public schools, he was graduated in 1897 from Southern Iowa Normal School and five years later from Iowa State Teachers College in Cedar Falls, Iowa. Ramseyer taught in Bloomfield for nine years, eventually serving as principal of Bloomfield High School. In 1906 he earned a law degree from The University of Iowa and commenced a practice in Bloomfield. A Republican, he was prosecuting attorney of Davis County from 1911 to 1915 and was elected in 1914 to the U.S. House of Representatives. By 1932, Ramseyer was in his ninth congressional term and a prestigious member of the Ways and Means Committee. From a predominantly rural district, he often promoted legislation benefiting agriculture and small business. ${ }^{2}$

I am indebted to the National Endowment for the Humanities for financial assistance in the preparation of this article.

2 Biographical Directory of the American Congress 1774-1971 (Washington: U.S. Government Printing Office, 1971). 
During Herbert Hoover's presidency the nation's economy had plunged. Between 1929 and 1933, the Gross National Product declined from $\$ 103$ billion to $\$ 55$ billion and per capita income from $\$ 847$ to $\$ 442$. Unemployment rose from 3 percent to over 25 percent of the total work force, encompassing around 12.6 million workers. Farmers especially experienced adverse conditions during the depression. Although agricultural production did not drop significantly, farm income fell 61 percent from $\$ 13$ billion to $\$ 5$ billion. ${ }^{3}$ Corn had declined from $\$ 2$ to 25 cents a bushel and hogs from $\$ 15$ to $\$ 3$ per hundredweight, with the result that Iowa farmers had considerable difficulty paying off debts. Farms were producing commodities that could not be disposed of, while many consumers lacked financial resources to purchase these goods. Iowa farmers, many of whom were burning corn for fuel, advocated major monetary reform and particularly favored restoring the purchasing power of the dollar.

Ramseyer championed the cause of Iowa farmers demanding monetary reform. According to Ramseyer, economic difficulties were caused by (1) taxation and increased national and international debts following World War I and (2) the decline in commodity prices. In order to enable farmers to pay their debts, he urged raising commodity prices to predepression levels and maintaining rates there. A moderate and controlled expansion of money and credit, Ramseyer argued, would restore the purchasing power of farmers and stimulate demand for factory products. ${ }^{4}$

Ramseyer began his campaign for monetary reform as a member of the Iowa State Bar Association. In June 1930, the association appointed Ramseyer to chair a committee studying the purchasing power of money. Although fellow Republican Representatives Letts and Fred C. Gilchrist served on the committee, Ramseyer wrote the entire report which was issued in June 1931, by the committee at the Iowa State Bar Association's annual convention in Des Moines. Gilchrist remarked, "Full credit must be given to him [Ramseyer] for the entire report as I had nothing to do with it and neither did Judge Letts." Ramseyer's committee, protesting the high unemployment rates and decline in the purchasing power of money, considered stabilization of the currency of critical importance to Iowa, a largely agricultural state dependent on satisfactory price levels. "Many of her citizens," Ramseyer's committee stated, "are debtors, who suffer the tragic con-

3 David A. Shannon, Between the Wars: America, 1919-1941, 2nd ed. (Boston: Houghton Mifflin, 1979), pp. 131-35.

4 For Ramseyer's views, see C. William Ramseyer Papers, The University of Iowa Libraries, Box 1, Correspondence 1931-1932. 
sequences when the price level declines." Besides preventing inflation and deflation, stabilization, it argued, would "prevent violent fluctuations in the price level." The committee recommended that the gold value in the dollar be determined by the commodity price level. ${ }^{5}$

During the summer of 1931, Ramseyer corresponded with agricultural journal editor Henry A. Wallace, Republican Congressman O. B. Burtness, and other farm experts on money problems. "The crop outlook here," Ramseyer wrote Burtness on July 11 from Bloomfield, "is splendid. Of course, the big trouble is the price of farm commodities." Two weeks later, Ramseyer commented to Burtness, "The more I reflect on our business and economic difficulties, the more I am impressed with the importance of setting up a control on the purchasing power of money." By early August, he favored granting the Federal Reserve Board additional authority to stabilize the purchasing power of money. ${ }^{6}$

Wallace, meanwhile, shared Ramseyer's concern about monetary problems. The son of a secretary of agriculture under Presidents Warren Harding and Calvin Coolidge, he edited the widely circulated and influential agricultural journal Wallaces' Farmer. Wallace, an expert plant geneticist and authority on hybrid corn, corresponded frequently with Ramseyer and other members of the Iowa congressional delegation. He not only advocated raising commodity prices to predepression levels, but he also urged keeping agricultural rates at that level. Besides favoring greater federal intervention on behalf of the farmer, he proposed reducing the output of chronic surplus crops and increasing the prices paid to farmers. ${ }^{7}$

Between August and October 1931, Ramseyer served on the American Farm Bureau Federation's Committee on the Stabilization of the Unit of Value. ${ }^{8}$ After several meetings in Chicago, the committee on October 9 and 10 urged Congress to pass a joint resolution authorizing the Federal Reserve Board to restore wholesale commodity prices to the 1926 or 1929 predeflationary levels. The

5 "Report of the Committee on Stabilizing the Purchasing Power of Money," June 18, 1931, Ramseyer Papers, Box 1, Corr. 1931; Fred C. Gilchrist to Rev. W. F. Clayburg, December 23, 1931, Henry A. Wallace Papers, The University of Iowa Libraries, Reel 11, Frames 390-91.

6 C. William Ramseyer to O. B. Burtness, July 11, 25, 1931, Ramseyer Papers, Box 1, Corr. 1931; C. William Ramseyer to John P. Wallace, August 4, 1931, Ramseyer Papers, Box 1, Corr. 1931.

7 For Wallace's views on agricultural problems, see Wallace Papers, Reels 8. 11, 13, 15; Ramseyer Papers, Box 1, Corr. 1931, 1932.

8 C. William Ramseyer to Henry A. Wallace, August 20, 1931, Wallace Papers, Reel 8, Frame 689. 
Federal Reserve Board, the committee suggested, should not only regulate the volume of currency in circulation, but it should also determine the cost of money and the expansion and contraction of bank credit. According to the committee, "nothing but an early and rapid increase in the wholesale commodity price level" could "save a large portion of the active producers."

On October 19, Ramseyer delivered a major address on monetary reform to the Association of Commerce in Centerville, Iowa. Blaming agricultural problems on the decline in commodity prices rather than overproduction, Ramseyer insisted that rates be restored quickly to predepression levels. "We," he declared, "want an honest dollar. A stabilized dollar is an honest dollar." Besides enabling farmers to pay debts and increase purchasing power, stabilization would help eliminate unemployment, maintain labor wage standards, and prevent many banks from collapsing. Ramseyer's speech was greeted enthusiastically by Iowa businessmen, farmers, country bankers, and laborers. ${ }^{9}$

Ramseyer, meanwhile, ardently championed the American Farm Bureau Federation committee plan in constituent correspondence and with the Iowa congressional delegation. "The deflation of the last two years," he warned one Iowan, "has resulted in many disasters." To another constituent, Ramseyer pleaded, "We must do everything possible to restore the commodity price level to what it was at the beginning of the present depression."10 Ramseyer also enlisted considerable support from the Iowa congressional delegation for the plan. Representative Lloyd Thurston stated, "I am in hearty accord with the movement, if it can be confined to the products of the farm," while Congressman Gilchrist remarked, "we will have found a remedy for many of our economic ills when we make the dollar more stable."11 According to veteran Representative Haugen, "it would undoubtedly enable many now in dire distress to cancel their indebtedness, and thus give them a new lease on life."12

During November, Ramseyer returned to Washington to confer with members of the Federal Reserve Board, legislative representatives of farm organizations, and several congressmen. He received

9 C. William Ramseyer Speech, October 19, 1931, Centerville, Iowa, Ramseyer Papers, Box 2, Speeches.

10 C. William Ramseyer to John Cowles, October 6, 1931, Ramseyer Papers, Box 1, Corr. 1931; C. William Ramseyer to D. L. Akerman, October 27, 1931, Ramseyer Papers, Box 1, Corr. 1931.

11 Lloyd Thurston to Henry A. Wallace, January 9, 1932, Wallace Papers, Reel 11, Frames 634-35; Gilchrist to Clayburg, December 23, 1931.

12 Gilbert N. Haugen to O. T. Knudtson, January I1, 1932, Gilbert N. Haugen Papers, State Historical Society of Iowa, Box 37. 
little support for his agricultural plan from Eugene Meyer and two other members of the Federal Reserve Board. "I didn't get much out of any of them," Ramseyer commented. "In fact I did not expect to." On the other hand, Ramseyer secured a much more favorable response from congressmen, "all of whom seem to be deeply interested in what our committee is trying to accomplish." Although not discussing the plan with all Iowa legislators, Ramseyer commented, "Those I have talked with are enthusiastic for it and undoubtedly others will line up when the time comes."13

At the same time, Ramseyer also concentrated on drawing up monetary legislation. At Ramseyer's request, prominent Yale University economist Irving Fisher wrote a complicated bill changing the gold content of the dollar so as to restore a predepression price level and stabilize the purchasing power of the dollar. Ramseyer considered the Fisher proposal too cumbersome and detailed and complained that it delegated more power to executive agencies than Congress would accept. Consequently, on December 7, Ramseyer introduced a shorter, simpler measure designating the Federal Reserve Board to use all its existing authority to restore the price level to that of 1926 and to stabilize rates on that basis. Besides boasting that the legislation would "do more good than anything else," he predicted "such a bill will have a chance of being reported out." Ramseyer's measure did not grant the Federal Reserve System any additional power but was designed to make it more effective in regulating the volume of currency in circulation, the cost of money, and the expansion and contraction of credit. Ramseyer vowed, "We are in the fight to win" and pledged, "I shall put forth all my energy to get an early consideration" of the measure. ${ }^{14}$ Several other representatives, including Burtness of North Dakota, T. Alan Goldsborough of Maryland, and James G. Strong of Kansas, also introduced similar agricultural legislation.

On December 8, Ramseyer addressed the annual convention of the American Farm Bureau Federation in Chicago. He described the drop in commodity prices and the consequent decline in farm purchasing power and stressed how his bill would remedy agricultural distress. Besides renewing appeals for "an honest dollar," Ramseyer insisted, "Nothing but an early and rapid increase in the wholesale com-

13 C. William Ramseyer to Ralph Snyder, November 12, 1931, Ramseyer Papers, Box 1, Corr. 1931; C. William Ramseyer to Henry A. Wallace, November 30, 1931, Wallace Papers, Reel 11, Frame 79.

14 Congressional Record, 71 Cong., 3 Sess., December 11, 1931, p. 494; January 11, 1932, p. 2,258; C. William Ramseyer to E. H. Sullivan, December 28, 1931, Ramseyer Papers, Box 1, Corr. 1931; C. William Ramseyer to R. Brown, December 4, 1931, Ramseyer Papers, Box 1, Corr. 1931. 
modity price level can save a large portion of the active producers of the United States." To secure "early and effective relief," he concluded, "we must have the united, militant, and organized support for the farmer of the United States."15 The American Farm Bureau Federation, along with the National Grange and the National Farmers Union, enthusiastically endorsed Ramseyer's message, giving considerable encouragement to the Iowa congressional delegation. Ramseyer asserted, "I believe with the united backing of the farm organizations we can get action," while colleague Gilchrist boasted, "Perhaps this is the first time, thank the Lord, that all three of them agreed on any specific thing." 16

In early January 1932, Ramseyer and other agrarian representatives intensified their campaign on Capitol Hill. On January 6, Ramseyer, joined by Burtness of North Dakota, Strong of Kansas, and Goldsborough of Maryland, sent all House members a publication entitled "Honest Money." Stabilization, they insisted, was "essential to permit debtors to retire their indebtedness, to safeguard the securities held by creditors including all financial institutions, and to restore general prosperity to the country, as well as to prevent recurring periods of depression in the future." Three days later, Ramseyer summoned around one hundred Congressmen to a conference at the Capitol to discuss monetary problems. At that session, the presidents of the National Grange, National Farmers Union, and American Farm Bureau Federation jointly recommended raising and stabilizing the commodity price level. "We demand," they concluded, "the adoption of effective measures to stabilize the purchasing power of money." $17 \mathrm{Al}$ though still facing a formidable task ahead, Ramseyer was determined to accomplish relief for distressed farmers. "It is the most important cause," he remarked in the middle of January, "with which I have been identified during my entire service in Congress. This is the one task that lies at hand. It is 'do' or 'die." " On the other hand, Ramseyer admitted, "It has been an uphill business to arouse interest in the subject among members of Congress. . . . We have had to do a lot of educating."18

15 C. William Ramseyer Speech, December 8, 1931, Chicago, Illinois, Ramseyer Papers, Box 2, Speeches.

16 Ramseyer to Sullivan, December 28, 1931; Fred C. Gilchrist to Henry A. Wallace, December 23, 1931, Wallace Papers, Reel 11, Frames 387-89.

17 C. William Ramseyer et al., to House Members, January 6, 1932, Ramseyer Papers, Box 1, Corr. 1932; Congressional Record, 71 Cong., 3 Sess., January 19,1932, p. 1932.

18 C. William Ramseyer to Chester H. Gray, January 18, 1933, Ramseyer Papers, Box 1, Corr. 1933-1942; C. William Ramseyer to H. B. Murray, March 25, 1932, Ramseyer Papers, Box 1, Corr. 1932. 
On January 16, Ramseyer delivered a nationwide address over the NBC radio network on the "National Farm and Home Hour." After explaining Iowa's agricultural problems and how his bill would remedy the situation, he fervently appealed to farmers, laborers, businessmen, and bankers across the nation to support increasing commodity prices to predepression levels. "The sooner we realize that this is the only way out of our difficulties and get busy," he stated, "the sooner we will begin to work out of this depression." Besides stressing that the major national agricultural organizations wholeheartedly supported the legislation, he vowed that raising and stabilizing commodity prices would "restore purchasing power to the farmers, employ labor, revive business, save many banks," and "make 1932 as the year of economic recovery." 19

In late January, Ramseyer joined several other representatives launching efforts to secure Banking and Currency Committee hearings on the monetary stabilization bills. A bipartisan group, including Burtness of North Dakota, Strong of Kansas, Goldsborough of Maryland, and Abe Sabath of Illinois, joined Ramseyer in coaxing the committee to conduct hearings. After these initial efforts failed, these representatives met on February 10 and pledged to start a campaign on the House floor for committee hearings. "There are at least a half dozen of us," Ramseyer noted, "ready to speak on the floor of the House on monetary stabilization." "Unless such hearings are forthcoming very soon," he warned, "we will have to commence with some strong arm methods." 20 Congress, however, was preoccupied with the comprehensive Reconstruction Finance Corporation bill and consequently delayed action on monetary stabilization. "As soon as it is safely out of the way," Ramseyer wrote, "we will start on the stabilization bills." At the same time, he was encouraged by the increased bipartisan congressional interest in monetary reform. "There has been a great change," he observed, "in the attitude of the members of Congress. . . . Now I think we should press for a hearing at the earliest date possible, while some of the nonpartisan spirit still prevails."2I

To Ramseyer's chagrin, the Banking and Currency Committee delayed hearings until March 16. Numerous witnesses, representing agricultural, economic, and business organizations and the Federal Re-

19 C. William Ramseyer, Speech, National Broadcasting Company, Washington, D.C., January 16, 1932, Ramseyer Papers, Box 2, Speeches.

20 C. William Ramseyer to Edward A. O'Neal, February 11, 1932, Ramseyer Papers, Box 1, Corr. 1932.

21 C. William Ramseyer to Henry A. Wallace, February 15, 22, 1932, Ramseyer Papers, Box 1, Corr. 1932. 
serve System, testified on the various monetary stabilization bills, further postponing any final committee action. Ramseyer had mixed emotions but was pleased that the committee was finally considering the monetary legislation. "Interest in the subject by the members of that committee," he observed in late March, "has increased." On the other hand, Ramseyer disliked the slow pace of committee action and was uncertain about the eventual congressional outcome. "We are making progress," he wrote, "but I realize it is slow." "I am hopeful," he added, "that action on the monetary bills can be obtained in the near future. If we do get the bill through the House there will still be a big fight ahead in the Senate." 22 A few days later, Ramseyer wrote one disenchanted constituent, "I am doing my very best to get action on this bill. I realize that conditions on the farms are intolerable."23

In late April, the Banking and Currency Committee completed action. After considering several similar bills, the committee reported out a measure (HR 10517) by Goldsborough of Maryland to restore commodity prices to the 1926 basis and to stabilize rates at that level. The Goldsborough bill directed the Federal Reserve Board, the Federal Reserve banks, and the Secretary of the Treasury to restore the average commodity price to the same level that existed when farmers and other producers contracted their debts. ${ }^{24}$ Labeling the Goldsborough bill as "a sound and constructive proposal," Ramseyer pledged, "I shall now exert my best efforts to get the bill passed by the House of Representatives at the earliest possible date."25

Ramseyer played an instrumental role in the House adoption of the Goldsborough measure. During floor debate on May 2, he urged colleagues to back the Goldsborough bill elevating and stabilizing commodity prices. Unless Congress acted expeditiously, he warned, "the whole financial structure will collapse and everything will go to pieces." On the same day, the House approved the Goldsborough measure by a decisive 289-60 margin, with the Iowa delegation giving unanimous approval. ${ }^{26}$ After a long, uphill battle, Ramseyer and the other agricultural bloc members had accomplished their ultimate ob-

22 C. William Ramseyer to Henry A. Wallace, March 2, 1932, Wallace Papers, Reel 13, Frame 153; Congressional Record, 71 Cong., 3 Sess., March 12, 1932, p. 5,894; Ramseyer to Murray, March 25, 1932.

23 C. William Ramseyer to Mrs. Zilpha Goodson, April 4, 1932, Ramseyer Papers, Box 1, Corr. 1932.

24 Congressional Record, March 12, 1932, p. 5,894.

25 C. William Ramseyer to W. L. Brown, May 18, 1932, Ramseyer Papers, Box 1, Corr. 1932; C. William Ramseyer to Mr. and Mrs. Lawrence Ward, April 22, 1932, Ramseyer Papers, Box 1, Corr. 1932.

26 Congressional Record, 71 Cong., 3 Sess., May 2, 1932, pp. 9,420, 9,432-33.

[22] 
jective in the House. "When the work was begun," Ramseyer recalled, "there were not over twenty Congressmen who had given this subject any thought." 27

The Senate, to the dismay of the Iowa delegation, scaled down the monetary measure. Conservative Democrat Carter Glass of Virginia, who opposed granting the Federal Reserve Board such extensive power, introduced a rider to the home loan bill stipulating that financial institutions issue nearly $\$ \mathrm{I}$ billion in currency based on government bonds bearing 3.375 percent interest. The Senate approved the Glass rider, thus discarding the more comprehensive Goldsborough bill. Representative Gilchrist, expressing the sentiments of the Iowa delegation, charged that the Glass rider was "a flank attack" and "subterfuge" that "will not accomplish what we want."28

During the New Deal, Congress approved farm legislation more in accordance with Ramseyer's objectives. The Agricultural Adjustment Act of 1933 restricted acreage under production and paid those farmers limiting production substantial benefits based on parity. The legislation was designed to give farmers the same level of purchasing power as that in effect immediately before World War I, the most prosperous agricultural period in American history. Financed by a tax on the processors of agricultural commodities, the Agricultural Adjustment Act stabilized farm prices and raised farm incomes substantially. In 1934 Congress established a $\$ 2$ billion fund to stabilize the dollar in international exchanges, thus producing an inflationary effect desired by farmers. ${ }^{29}$

This monetary battle was the last major legislative campaign for Ramseyer in the House. Because of reapportionment caused by the 1930 census, the Iowa House delegation was reduced from eleven to nine seats, forcing Republican incumbents Ramseyer and Thurston to run against each other. Thurston defeated Ramseyer in the 1932 primary, bringing to an end the Bloomfield representative's congressional career. President Herbert Hoover in 1933 appointed Ramseyer a commissioner for the United States Court of Claims, a position

27 C. William Ramseyer to J. E. Cross, May 23, 1932, Ramseyer Papers, Box 1, Corr. 1932.

28 Fred C. Gilchrist to Henry A. Wallace, August 6, 1932, Wallace Papers, Reel 15, Frame 459.

29 For the Agricultural Adjustment Act of 1933, see William E. Leuchtenburg, Franklin D. Roosevelt and the New Deal 1932-1940 (New York: Harper \& Row, 1963) and Van L. Perkins, Crisis in Agriculture: The Agricultural Adjustment Act and the New Deal (Berkeley: University of California Press, 1969). For New Deal monetary legislation, see John A. Brennan, Silver and the First New Deal (Reno: University of Nevada Press, 1969) and David L. Porter, Congress and the Waning of the New Deal (Port Washington, N.Y.: Kennikat Press, 1980). 
which he held until his death on November 1, 1943 in Washington, D.C. ${ }^{30}$

Ramseyer considered the drive for monetary legislation the most significant battle of his congressional career. Besides serving on the Iowa State Bar Association and American Farm Bureau Federation committees, he consulted with economists and agricultural organizations, drafted a monetary bill, organized congressional support for higher commodity prices, and delivered several speeches on behalf of monetary reform legislation. In addition, Ramseyer was instrumental in securing favorable action from the House Banking and Currency Committee and the representatives as a whole on the Goldsborough bill. Upon witnessing the deplorable agricultural conditions faced by Iowa farmers in the depression, Ramseyer proposed a simple yet effective way for enabling farmers to pay their debts.

30Biographical Directory of the American Congress 1774-1971 provides a sketch of Ramseyer's political career. Francis O. Wilcox, "Congressional Redistricting in Iowa," Iowa Journal of History and Politics, 29 (October 1931): 461517 , and Des Moines Register, November 2, 1932, discuss the impact of redistricting. 